\title{
PENGARUH INVESTMENT OPPORTUNITY SET, DIVIDEND PAYOUT RATIO DAN MEKANISME CORPORATE GOVERNANCE TERHADAP NILAI PERUSAHAAN PADA PERUSAHAAN MANUFAKTUR YANG TERDAFTAR DI BURSA EFEK INDONESIA
}

\author{
Nur Insyiroh Syafda' \\ Abriyani Puspaningsih ${ }^{2}$
}

\begin{abstract}
This research was aimed to expose the effect of Investment Opportunity Set, Dividend Payout Ratio and Corporate Governance Mechanism to the Company's Value. In this research, company's value was measured by Tobin's Q. Corporate Governance Mechanism were measured by audit committee, independent directors, institutional ownership and managerial ownership.

Sampels in this research were 14 manufacturing company that listed at Indonesian Stock Exchange 2008 - 2010. Data processing in this research was supported by statistic program (SPSS). The data analysis was carried on by regression analysis.

The result from the analysis showed that Investment Opportunity Set, independent directors, institutional ownership and managerial ownership were affected to company's value. Dividend Payout Ratio and audit committee were not affected to company's value.

Keywords : Corporate Governance, Dividend Payout Ratio, Investment Opportunity Set, Tobin's $Q$.

\section{Pendahuluan}

Dalam era persaingan global seperti saat ini perusahaan perusahaan harus dikelöla dengan baik dan cermat. Dengan pengelolaan yang baik, dalam jangka waktu panjang tentu dapat mengoptimalkan nilai perusahaan dan memaksimumkan kemakmuran pemegang saham. Kemakmuran para pemegang saham dapat dilihat dari nilai perusahaannya, semakin tinggi nilai perusahaan, semakin tinggi pula kemakmuran pemegang saham.
\end{abstract}

Investment Opportunity Set menunjukkan investasi perusahaan atau opsi pertumbuhan. Perusahaan yang memiliki kemampuan tumbuh atau berinvestasi yang tinggi pada akhirnya akan mempengaruhi kinerja perusahaan. Perusahaan yang memiliki kesempatan tumbuh yang tinggi pada umumnya membutuhkan dana eksternal untuk melakukan ekspansi. Hal ini mendorong perusahaan untuk melakukan perbaikan dalam penerapan Corporate Governance dalam rangka untuk menurunkan biaya modal (Darmawati, 2005).

Kebijakan dividen merupakan hal yang berpengaruh pada nilai perusahaan. Manajer harus dapat mempertimbangkan secara tepat apakah laba yang diperoleh perusahaan akan dibagikan kepada pemegang saham sebagai dividen atau akan ditahan dalam bentuk "laba ditahan" guna pembiayaan investasi di masa yang akan datang.

Komite audit memiliki peran penting dalam implementasi Good Corporate Governance. Dengan adanya fungsi komite audit yang berjalan dengan baik, maka pengendalian terhadap perusahaan menjadi lebih baik, sehingga konflik keagenan yang mungkin terjadi dapat diminimalisir.

Adanya komisaris independen diharapkan mampu meningkatkan peran dewan komisaris agar tercipta Good Corporate Governance di dalam perusahaan. Dalam penelitian

\footnotetext{
1 Alumnus Jurusan Akuntansi FE Ull Yogyakarta

2 Dosen Jurusan Akuntansi FE UII Yogyakarta
} 
Herawaty (2008) menyatakan bahwa komisaris independen berpengaruh signifikan terhadap nilai perusahaan.

Struktur kepemilikan (kepemilikan manajerial dan kepemilikan institusional) oleh beberapa peneliti dipercaya mampu mempengaruhi jalannya perusahaan yang pada akhirnya berpengaruh pada kinerja perusahaan dalam mencapai tujuan perusahaan yaitu maksimalisasi nilai perusahaan. Hal ini disebabkan oleh karena adanya kontrol'yang mereka miliki (Wahyudi dan Pawestri, 2006).

Penelitian ini bertujuan untuk menganalisis pengaruh Investment Opportunity Set, Dividend Payout Ratio dan mekanisme Corporate Governance (komite audit, komisaris independen, kepemilikan institusional, dan kepemilikan manajerial) terhadap nilai perusahaan.

\section{Kajian Pustaka}

\section{Nilai Perusahaan}

Bringham dan Gapenski (1996) menyatakan nilai perusahaan sangat penting, karena nilai perusahaan yang tinggi akan diikuti oleh tingginya kemakmuran pemegang saham. Semakin tinggi harga saham semakin tinggi pula nilai perusahaan. Eugine Fama (1978) menyatakan bahwa nilai perusahaan akan tercermin dari harga sahamnya.

\section{Faktor-Faktor Yang Mempengaruhi Nilai Perusahaan}

a. Investment Opportunity Set

Menurut Fama (1978) nilai perusahaaan ditentukan oleh keputusan investasi. Keputusan investasi itu penting, karena untuk mencapai tujuan perusahaan dapat diraih melalui kegiatan investasi perusahaan (Modigliani dan Miller, 1958). Kallapur dan Trombley (2001) menyatakan bahwa kesempatan investasi perusahaan merupakan - komponen penting dari nilai pasar. Investment Opportunities. Set merupakan nilai perusahaan yang besarnya tergantung pada pengeluaran-pengeluaran yang ditetapkan manajemen di masa yang akan datang.

b. Dividen Payout Ratio

Kebijakan dividen merupakan keputusan apakah laba yang diperoleh perusahaan pada akhir tahun akan dibagi kepada pemegang saham di masa yang akan datang. Pada dasarnya Dividen Payout Ratio adalah menentukan jumlah laba yang dibagi dalam bentuk dividen kas dan laba yang ditahan sebagai sumber pendanaan. Rasio ini menunjukkan presentase laba perusahaan yang dibayarkan kepada pemegang saham biasa perusahaan berupa dividen kas.

\section{c. Corporate Governance}

Corporate Governance memiliki tujuan untuk menciptakan nilai tambah bagi semua pihak yang berkepentingan (stakeholders). Menurut Chen (2008), mekanisme Corporate Governance yang efektif dapat berdampak besar pada pengambilan keputusan secara tepat waktu dalam suatu bisnis yang dijalankan oleh perusahaan, yang hal ini dapat berakibat peningkatan nilai perusahaan.

d. Komite Audit

Komite audit mempunyai peran yang sangat penting dan strategis dalam hal memelihara kredibilitas proses penyusunan laporan keuangan seperti halnya menjaga terciptanya sistem pengawasan perusahaan yang memadai serta dilaksanakannya Good Corporate Governance. Dengan adanya komite audit yang efektif diharapkan 
tindak manajemen laba dapat dibatasi. Di Indonesia keberadaan komite audit dipertegas dengan keputusan Bapepam yang dituangkan dalam SE BAPEPAM No. 03 tahun 2000 mengenai pembentukan komite audit dan juga Keputusan Direksi BEJ No. 339 tahun 2001 mengenai peraturan pencatatan efek di Bursa yang mencakup komisaris independen, komite audit, sekretaris perusahaan; keterbukaan; dan standar laporan keuangan per sektor.

e. Komisaris Independen

Komisaris independen adalah anggota dewan komisaris yang tidak terafiliasi dengan direksi, anggota dewan komisaris lainnya dan pemegang saham pengendali, serta bebas dari hubungan bisnis atau hubungan lainnya yang dapat mempengaruhi kemampuannya untuk bertindak independen atau bertindak samata-mata demi kepentingan perusahaan. Praktik Corporate Governance mengharuskan adanya komisaris independen dalam perusahaan yang diharapkan mampu mendorong dan menciptakan iklim yang lebih independen, objektif, dan menempatkan kesetaraan sebagai prinsip utama dalam memperhatikan kepentingan pemegang saham minoritas dan stakeholder lainnya.

f. Kepemilikan Institusional

Institusi yang melakukan investasi akan memantau secara profesional perkembangan investasinya. Keberadaan institusi inilah yang mampu menjadi alat monitoring efektif bagi perusahaan (Etty Murwaningsari, 2009). Dengan adanya monitoring tersebut maka hal ini akan meningkatkan kepercayaan investor, yang pada akhirnya dapat menaikkan nilai perusahaan.

g. Kepemilikan Manajerial

Jensen dan Meckling (1976) menyatakan bahwa untuk meminimalkan konflik keagenan adalah dengan meningkatkan kepemilikan manajerial dalam perusahaan. Ross et al (1999) dalam Siallagan dan Machfoedz (2006) menyatakan bahwa dengan kepemilikan manajerial dalam perusahaan, maka manajemen akan cenderung berusaha meningkatkan kinerjanya untuk kepentingan pemegang saham dan kepentingannya sendiri.

\section{Pengembangan Hipotesis}

\section{a. Pengaruh Investment Opportunity Set terhadap Nilai Perusahaan}

Di dalam melakukan investasi, jika risiko lebih besar investor mengharapkan return yang lebih besar. Jika profitabilitas perusahaan tercapai, maka perusahaan dapat membagikan dividen yang besar dan secara tidak langsung harga saham naik, dan tentunya berpengaruh pada naiknya nilai perusahaan. Hal ini sama dengan hasil penelitian yang dilakukan oleh Sri Hasnawati (2005) yang menyatakan investment opportunity berpengaruh positif terhadap nilai perusahaan. Berdasarkan uraian di atas, maka hipotesis yang dapat diajukan adalah:

$\mathrm{H}_{1}$ : Investment Opportunity Set berpengaruh positif terhadap nilai perusahaan.

\section{b. Pengaruh Dividen Payout Ratio terhadap Nilai Perusahaan}

Adanya pembayaran dividen dapat mengakibatkan kenaikan harga saham. Kenaikan pembayaran dividen merupakan signal bahwa perusahaan memiliki prospek yang baik. Sebaliknya penurunan pembayaran dividen akan dilihat sebagai prospek perusahaan yang kurang baik. Penelitian Rika Susanti (2010) menguji variabel dividen payout ratio 
yang merupakan proksi dari variabel deviden menunjukkan deviden berpengaruh positif dan tidak signifikan terhadap nilai perusahaan. Berdasarkan urajan di atas, maka hipotesisyang dapat diajukan adalah:

$\mathrm{H}_{2}$ : Deviden Payout Ratio berpengaruh positif dengan nilai perusahaan.

\section{c. Pengaruh Komite Audit Independen terhadap Nilai Perusahaan}

Penelitian Xie, Davidson dan Dadalt (2003) menguji efektifitas komite audit dalam mengurangi manajemen laba yang dilakukan oleh pihak manajemen. Hasil penelitiannya menyebutkan bahwa komite audit yang berasal dari luar mampu melindungi kepentingan pemegang saham dari tindakan manajemen laba yang dilakukan oleh pihak manajemen, dengan demikian diharapkan nilai perusahaan akan meningkat. Berdasarkan uraian di atas, maka hipotesis yang dapat diajukan adalah:

$\mathrm{H}$ : Keberadaan komite audit berpengaruh positif terhadap nilai perusahaan.

d. Pengaruh Komisaris Independen terhadap Nilai Perusahaan

Penelitian yang dilakukan oleh Herawaty (2008) menunjukkan adanya hubungan positif antara corporate governance dan nilai perusahaan. Berdasarkan uraian di atas, maka hipotesis yang dapat diajukan adalah:

$\mathrm{H}$ : Komposisi dewan komisaris independen berpengaruh positif terhadap nilai perusahaan.

e. Pengaruh Kepemilikan Institusional Terhadap Nilai Perusahaan

Dalam hubungannya dengan fungsi monitor, investor institusional diyakini memiliki kemampuan untuk memonitor tindakan manajemen lebih baik dibandingkan investor individual. Untuk menghindari tindakan likuidasi dari investor, manajer akan melakukan earnings management. Berdasarkan uraian di atas, maka hipotesis yang dapat diajukan adalah:

$\mathrm{H}_{5}$ : Kepemilikan institusional berpengaruh positif terhadap nilai perusahaan.

f. Pengaruh Kepemilikan Manajerial terhadap Nilai Perusahaan

Rachmawati dan Triatmoko (2007) yang menemukan kepemilikan manajerial berpengaruh positif terhadap nilai perusahaan dan juga penelitian Wahyudi dan Pawestri (2006) yang hasilnya adalah struktur kepemilikan manajerial berpengaruh terhadap nilai perusahaan baik secara langsung maupun melalui keputusan pendanaan. Berdasarkan uraian di atas, maka hipotesis yang dapat diajukan adalah:

$\mathrm{H}$ : Kepemilikan manajerial berpengaruh positif terhadap nilai perusahaan.

g. Model Penelitian

Berdasarkan teori yang sudah dikemukakan di atas, maka model penelitian dalam penelitian ini adalah sebagai berikut: 
UNISIA, Vol. XXXIV No. 77 Juli 2012

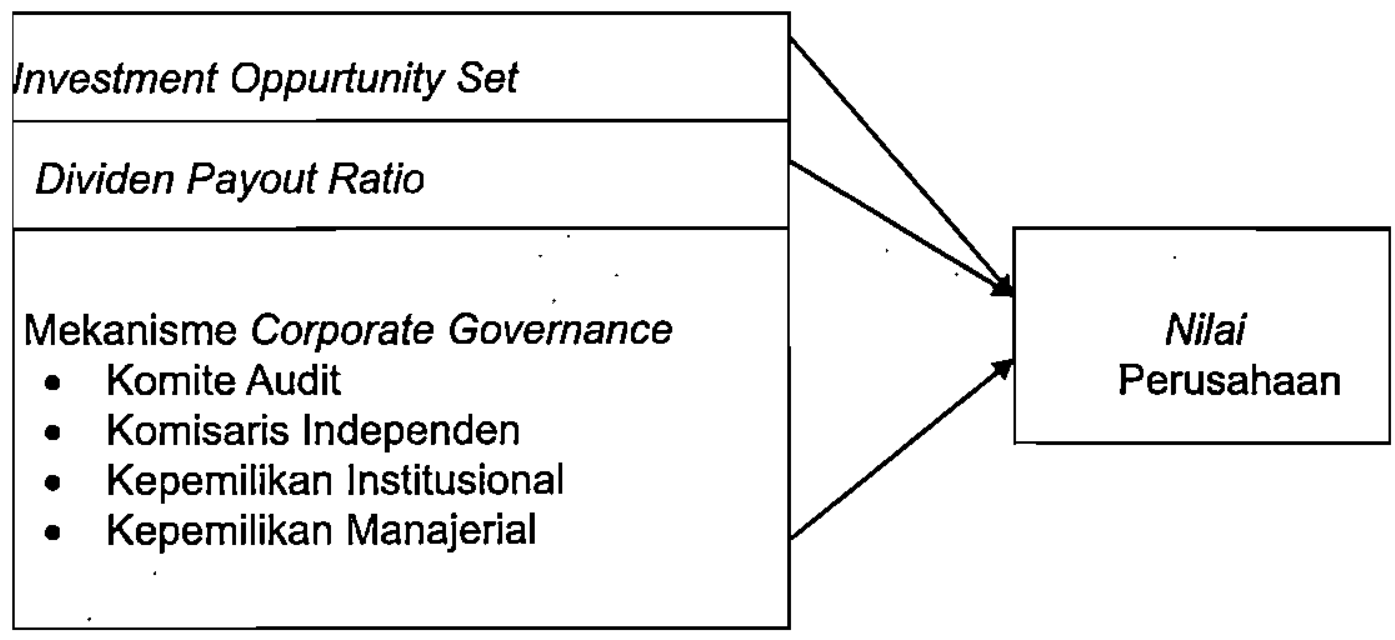

\section{Metode Penelitian}

\section{Populasi dan Sampe]}

Populasi dalam penelitian ini adalah perusahaan-perusahaan manufaktur yang terdaftar di Bursa Efek Indonesia pada periode 2008 sampai 2010. Sampel dalam penelitian ini dipilih menggunakan metode purposive sampling. Adapun kriteria-kriteria yang digunakan adalah sebagai berikut :

a. Perusahaan manufaktur yang terdaftar di Bursa Efek Indonesia dan mempublikasikan laporan keuangannya pada tahun 2008, 2009, dan 2010.

b. Laporan keuangan disajikan dalam rupiah dan semua data yang dibutuhkan untuk penelitian ini tersedia dengan lengkap (data secara keseluruhan tersedia pada publikasi periode 31 Desember 2008, 2009, dan 2010).

c. Perusahaan yang memiliki data mekanisme Corporate Governance di tahun 2008,2009 , dan 2010.

d. Perusahaan yang membagi dividen saham 3 tahun berturut-turut selama tahun 2008, 2009, dan 2010.

\section{Variabel dan Pengukuran Variabel}

\section{a. Nilai Perusahaan}

Nilai perusahaan diukur menggunakan Tobins $Q$ yaitu perbandingan antara market value of equity ditambah debt dengan book value of equity ditambah dengan debt. Menurut Herawati (2008) menyebutkan bahwa nilai perusahaan diukur melalui Tobins $Q$, yang diformulasikan :

Keterangan:

$$
\text { Tobins } \mathbf{Q}=\frac{\text { MVE }}{\text { BVE }}
$$

Tobin's $Q=$ Nilai perusahaan.

MVE = Nilai pasar dari ekuitas (Market Value Equity).

BVE = Nilai buku dari ekuitas (Book Value Equity).

$\mathrm{D}=\quad$ Nilai buku dari total hutang (Debt). 
Market Value Equity (MVE) diperoleh dari hasil perkalian harga saham penutupan akhir tahun dengan jumlah saham yang beredar pada akhir tahun. Book Value Equity (BVE) diperoleh dari selisih total assets perusahaan dengan total kewajibannya.

\section{b. Variabel Investment Opportunity Set}

Dalam mengukur Investment Oppurtunity Set pengukuran market value to book value of assets memiliki pengaruh yang besar terhadap perusahaan.

MVBVA $=\frac{\text { Asset }- \text { Ekuitas + (Saham Beredar } \times \text { Harga) }}{\text { Total Assets }}$

\section{c. Dividen Payout Ratio}

Kebijakan dividen menyangkut tentang penggunaan laba yang menjadi hak para pemegang saham. Pada dasarnya laba tersebut bisa dibagi sebagai dividen atau ditahan untuk diinvestasikan kembali. (Sri Hasnawati, 2005). Variabel dividen payout ratio diformulasikan sebagai berikut:

Dimana:

Dividen Payout Ratio $=\frac{\text { DPS }}{\text { EPS }}$

DPR : dividen payout ratio

DPS : dividen per share

EPS : earning per share

d. Mekanisme Corporate Governance

d.1. Keberadaan Komite Audit

Variabel ini merupakan variabel dummy. Bagi perusahaan yang memiliki komite audit maka akan mendapat nilai 1 , sedangkan perusahaan yang tidak memiliki komite audit mendapat nilai 0 .

\section{d.2. Komposisi Komisaris Independen}

Komposisi Dewan Komisaris diukur dengan persentase jumlah komisaris independen terhadap jumlah total komisaris yang ada,dalam susunan dewan komisaris.

\section{d.3. Kepemilikan Institusional}

Variabel kepemilikan institusional diukur dengan besarnya persentanse saham yang dimiliki oleh investor institusional.

d.4. Kepemilikan Manajerial .

Kepemilikan Manajerial diukur dengan besarnya persentase saham yang dimiliki oleh pihak manajemen perusahaan.

\section{Metode Analisis Data}

Data dalam penelitian ini dianalisis secara kuantitatif dengan menggunakan metode regresi linier berganda, dengan persamaan regresi sebagai berikut:

$$
N P=\beta_{0}+\beta_{1} I O S+\beta_{2} D P R+\beta_{3} K A U+\beta_{4} K I+\beta_{5} I N S T+\beta_{8} M A N J+\varepsilon
$$


UNISIA, Vol. XXXIV No. 77 Juli 2012

Keterangan:

$\mathrm{NP}=$ Nilai perusahaan

IOS = Investment Opportunity Set

DPR $=$ Dividen Payout Ratio

$\mathrm{KAU}$. = Keberadaan komite audit

$\mathrm{KI}=$ Komposisi komisaris independen

INST $=$ Kepemilikan institusional

MANJ = Kepemilikan manajerial

$\varepsilon \quad=$ error term

\section{Hasil Penelitian}

\section{Sampel Penelitian}

Berdasarkan metode purposive sampling dan kriteria-kriteria pengambilan sampel yang telah ditetapkan terpilih 14 perusahaan di setiap tahunnya. Berikut ini cara perolehan sample tersebut:

Tabel 1. Penentuan Jumlah Sampel

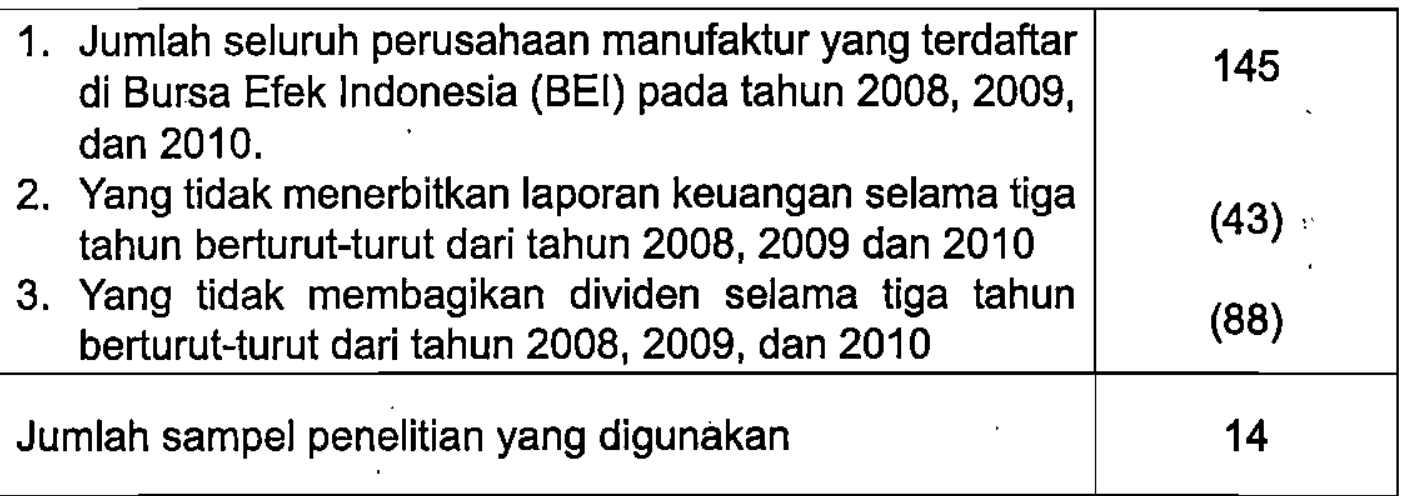

Perusahaan yang dijadikan sample disajikan pada tabel 2 berikut ini:

Tabel 2. Sampel Perusahaan

\begin{tabular}{|c|l|l|}
\hline No. & \multicolumn{1}{|c|}{ Kode } & \multicolumn{1}{c|}{ Nama Perusahaan } \\
\hline 1 & BATA & Sepatu Bata \\
\hline 2 & CLPI & Colorpark Indonesia \\
\hline 3 & DVLA & Darya Varia Laboratoria \\
\hline 4 & FAST $\quad$ & Fast Food Indonesia \\
\hline 5 & IGAR & Kageo Igarjaya \\
\hline 6 & IKBI & Sumi Indo Kabel \\
\hline 7 & INTA & Intraco Penta \\
\hline 8 & MAIN & Malindo Feedmill \\
\hline 9 & MLBI & Multi Bintang Indonesia \\
\hline 10 & MRAT & Mustika Ratu \\
\hline 11 & MTDL & Metrodata Electronics \\
\hline 12 & SMGR & Semen Gresik \\
\hline 13 & TSPC & Tempo Scan Pasific \\
\hline 14 & UNTR & Unite Tractor \\
\hline
\end{tabular}




\section{Statistik Deskriptif}

Hasil dari pengujian statistik deskriptif atas keenam variabel independen dan satu variabel dependen yang digunakan dalam penelitian ini, maka diperoleh hasil sesuai dengan tabel 3 berikut:

Tabel 3. Descriptive Statistics

\begin{tabular}{|l|c|c|c|c|c||}
\hline & $\mathrm{N}$ & Minimum & Maximum & Mean & Std. Deviation \\
\cline { 2 - 6 } & Statistic & Statistic & Statistic & Statistic & Statistic \\
\hline $\mathrm{NP}$ & 42 & .33 & 4.65 & 1.5619 & 1.05387 \\
IOS & 42 & .33 & 4.65 & 1.5796 & 1.04185 \\
DPR & 42 & .00 & 1.42 & .2804 & .26172 \\
KA $U$ & 42 & .00 & 1.00 & .3571 & .48497 \\
KI & 42 & .00 & .67 & .3655 & .15603 \\
INST & 42 & .12 & .95 & .7529 & .21481 \\
MANJ & 42 & .00 & .90 & .0435 & .14752 \\
Valid N & 42 & & & & \\
(listwise) & 42 & & & & \\
\hline
\end{tabular}

\section{Uji Asumsi Klasik}

Dari hasil Uji multikolinearitas diketahui bahwa semua variabel bebas mempunyai nilai toleransi lebih besar dari 0,1 dan nilai VIF kurang dari 10, sehingga dapat disimpulkan bahwa tidak terjadi gejala multikolinearitas dalam model penelitian ini. Hal ini berarti bahwa semua variabel bebas tersebut layak digunakan sebagai prediktor.

Dari hasil uji. Durbin-Watson menunjukkan nilai 2,052 yang posisinya terletak antara 1,66 hingga 2,34 yang berada pada kisaran tidak ada autokorelasi, oleh sebab itu dapat disimpulkan bahwa tidak terdapat autokorelasi pada persamaan regresi dalam penelitian ini.

Dalam penelitian ini, uji heterokedastisitas dilakukan dengan menggunakan analisis grafik Scatter Plot antara nilai prediksi variabel terikat ZPRED dengan residualnya SRESID. Grafik Scatter Plot ini dapat ditunjukkan pada gambar 1 berikut ini :

\section{Gambar. 1}

\section{Scatterplot}

Dependent Variable: NP

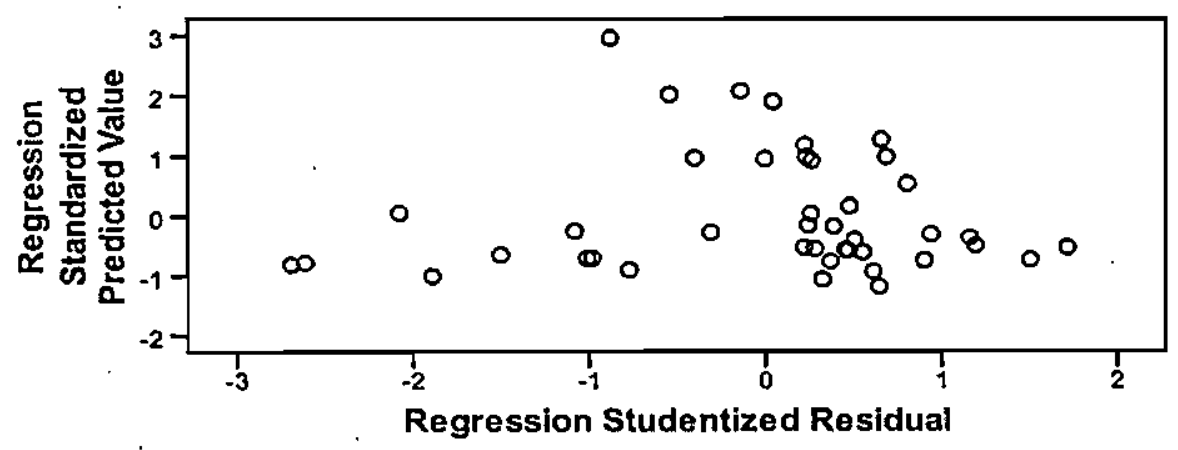

Grafik Scatter Plot di atas menjelaskan bahwa data sampel tersebar secara acak dan tidak membentuk suatu pola tertentu. Hal ini menunjukkan tidak terdapat heterokodestisitas dalam model regresi yang digunakan. 
UNISIA, Vol. XXXIV No. 77 Juli 2012

Hasil Uji normalitas inj dapat ditunjukkan dalam gambar 2 sebagai berikut: Gambar 2

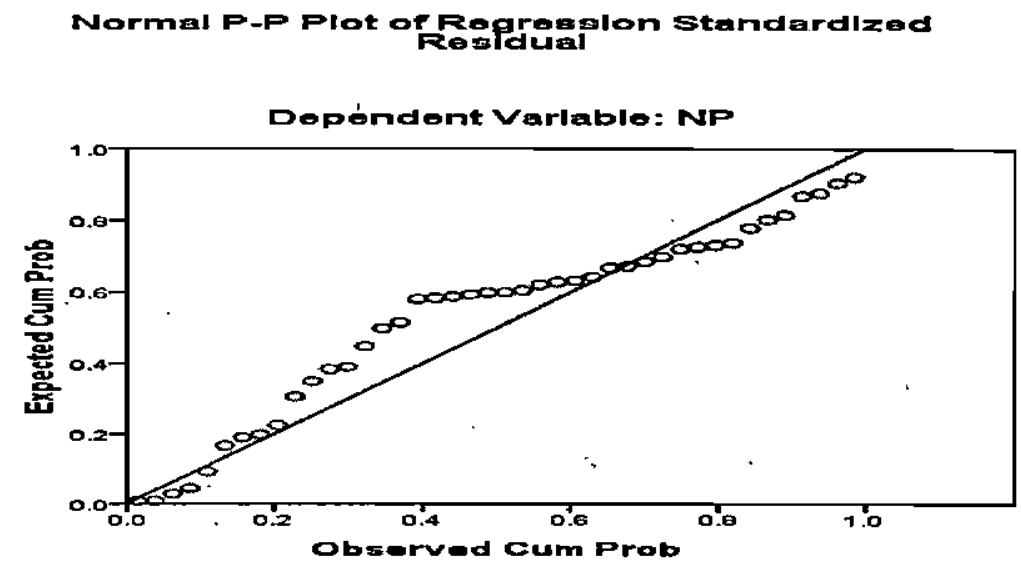

Dilihat dari gambar grafik normalitas di atas (Normal P-Plot of Regression Standardized Residual) terlihat bahwa titik-titik menyebar di sekitar garis diagonal, hal ini menunjukkan bahwa model regresi layak dipakai karena memenuhi asumsi normalitas.

\section{Uji Hipotesis}

Berdasar hasil regresi berganda, maka persamaan regresi pada penelitian ini adalah sebagai berikut :

$$
N P=\beta_{0}+\beta_{1} I O S+\beta_{2} D P R+\beta_{3} K A U+\beta_{4} \mathrm{KI}+\beta_{5} I N S T+\beta_{6} M A N J+\varepsilon
$$

Tabel 4. Hasil Regresi Berganda

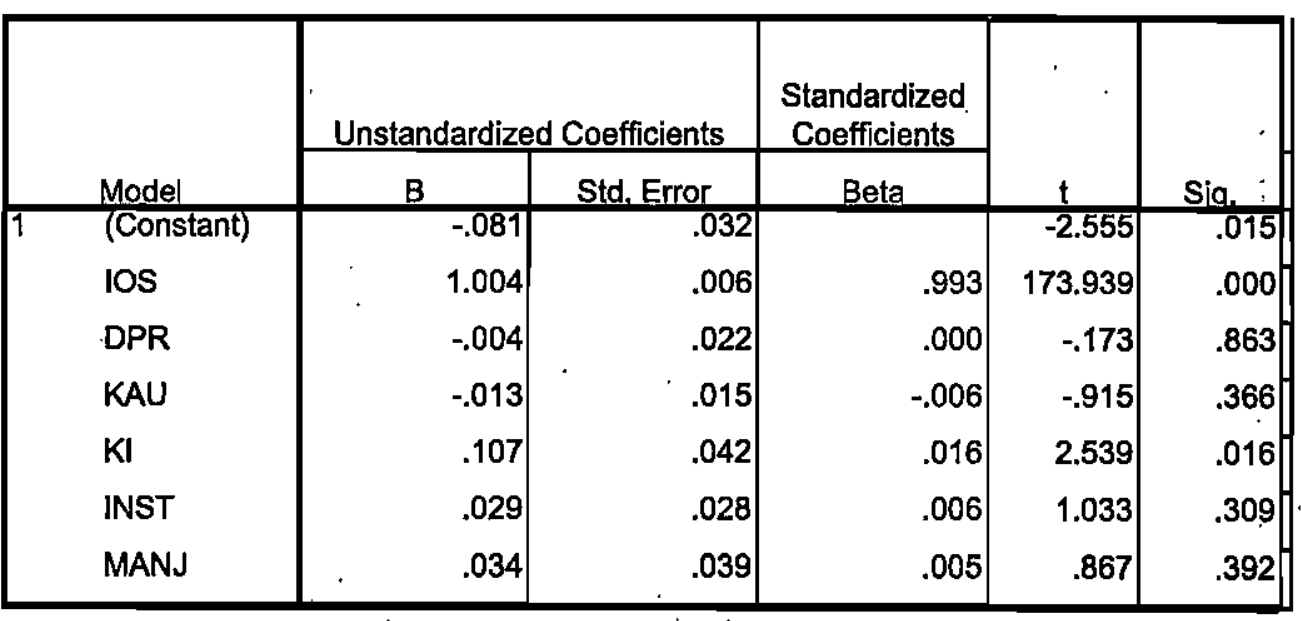

. Dari hasil analisis regresi linier berganda yang telah dilakukan, maka didapat model regresi linier berganda sebagai berikut:

$$
\mathrm{NP}=-0,081+1,004_{\mathrm{IOS}}-0,004_{\mathrm{DPR}}-0,013_{\mathrm{KAU}}+0,107_{\mathrm{KI}}+0,029_{\mathrm{INST}}+0,034_{\text {MANJ }}+\varepsilon
$$

\section{Pengujian Hipotesis Pertama}

Berdasarkan tabel 4 menunjukkan Investment Opportunity Set memiliki pengaruh positif $(1,004)$ dan signifikan $(0,000)$ terhadap nilaj perusahaan. Hal ini menunjukkan bahwa hipotesis - 1 terbukti. Semakin tinggi tingkat pertumbuhan perusahaan, maka semakin besar harapan investor akan prospek masa depan sehingga berpengaruh positif terhadap peningkatan nilaj perusahaan. 
Hasil penelitian ini sesuai dengan penelitian Rachmawati dan Triatmoko (2007) yang menyatakan bahwa Investment Opportunity Set berpengaruh secara positif terhadap nilai perusahaan. Hasil penelitian ini juga mendukung pernyataan bahwa pengeluaran investasi memberikan sinyal positif tentang pertumbuhan perusahaan di masa yang akan datang, sehingga meningkatkan harga saham sebagai indikator nilai perusahaan pada penelitian Wahyudi dan Pawestri (2006).

\section{Pengujian Hipotesis Kedua}

Berdasarkan tabel 4 menunjukkan Dividen Payout Ratio tidak berpengaruh. positif $(-0,004)$ terhadap nilai perusahaan. Hal ini menunjukkan bahwa hipotesis 2 tidak terbukti, yang berarti bahwa secara individu Dividen Payout Ratio tidak berpengaruh positif terhadap nilai perusahaan. Hal ini dikarenakan pada sampel penelitian yang dilakukan dalam pembayaran dividen di setiap perusahaan membagikan dividen dengan nominal yang sangat kecil.

Hasil dari penelitian ini bertolak belakang dengan hasil penelitian yang dilakukan oleh Sri Hasnawati (2005) yang menyimpulkan bahwa kebijakan dividen yang di ukur oleh Dividen. Payout Ratio berpengaruh positif terhadap nilai perusahaan.

\section{Pengujian Hipotesis Ketiga}

Berdasarkan tabel 4 menunjukkan keberadaan Komite Audit memiliki hubungan tidak berpengaruh positif $(-0,013)$ terhadap nilai perusahaan. Hal ini menunjukkan bahwa hipotesis 3 tidak terbukti yang berarti bahwa secara individu keberadaan Komite Audit tidak berpengaruh positif terhadap nilai perusahaan. Hal ini mengindikasikan bahwa semakin kecil komite audit maka semakin kecil pula nilai perusahaan. Semakin rendahnya komite audit yang dimiliki perusahaan menyebabkan fungsi komite audit tidak berjalan secara efektif, maka kontrol terhadap perusahaan tidak baik terhadap nilai perusahaan.

Hasil penelitian ini tidak sesuai dengan penelitian Siallagan dan Machfoedz (2006) yang menyatakan bahwa keberadaan komite audit mempunyai pengaruh positif terhadap nilai perusahaan.

\section{Pengujian Hipotesis Keempat}

Berdasarkan tabel 4 menunjukkan komposisi Komisaris Independen memiliki pengaruh positif $(0,107)$ terhadap nilai perusahaan. Hal ini menunjukkan bahwa hipotesis 4 terbukti, yang berarti bahwa secara individu komposisi dewan komisaris mempunyai pengaruh positif. terhadap nilai perusahaan. Ini berarti, pengawasan atas pengelolaan perusahaan oleh dewan komisaris independen semakin baik sehingga kinerja perusahaan akan meningkat dan nilai perusahaan akan meningkat.

Hasil penelitian ini sejalan dengan penelitian yang dilakukan oleh Herawaty (2008) yang dalam penelitiannya menunjukkan adanya hubungan positif antara corporate governance dan nilai perusahaan.

\section{Pengujian Hipotesis Kelima}

Berdasarkan tabel 4 menunjukkan kepemilikan institusional memiliki pengaruh positif $(0,029)$ terhadap nilai perusahaan. Hal ini menunjukkan bahwa hipotesis 5 terbukti, yang berarti bahwa secara individu kepemilikan institusional mempunyai pengaruh positif terhadap nilai perusahaani. Semakin tinggi kepemilikan institusional dipercaya mampu mempengaruhi jalannya perusahaan yang pada akhirnya berpengaruh pada kinerja perusahaan dalam mencapai tujuan utama perusahaan, yaitu memaksimalkan nilai perusahaan. 
UNISIA, Vol. XXXIV No. 77 Juli 2012

Hasil penelitian ini tidak sepaham dengan penelitian yang dilakukan oleh Zangina Ishaaq (2009) yang menunjukkan adanya hubugan negatif antara ownership structure dengan nilai perusahaan.

\section{Pengujian Hipotesis Keenam}

Berdasarkan tabel 4 menunjukkan kepemilikan manajerial memiliki pengaruh positif $(0,034)$ terhadap nilai perusahaan. Hal ini menunjukkan bahwa hipotesis 6 terbukti, yang berarti bahwa secara individu kepemilikan manajerial mempunyai pengaruh positif terhadap nilai perusahaan. Semakin tinggi struktur kepemilikan manejerial perusahaan maka nilai perusahaan akan meningkat, dengan kepemilikan manajerial akan mendorong manajemen untuk meningkatkan kinerja perusahaan karena mereka juga merasa memiliki perusahaan sehingga meningkatkan nilai perusahaan.

Hasil ini sesuai dengan penelitian yang dilakukan Jensen dan Meckling (1976) yang menyebutkan bahwa dengan peningkatan kepemilikan manajerial yang lebih baik dapat menyelaraskan kepentingan manajer dan pemegang saham sehingga dapat meningkatkan nilai perusahaan.

\section{Kesimpulan}

Dari penelitian yang dilakukan dapat disimpulkan sebagai berikut:

1. Investment Opportunity Set mempunyai pengaruh positif terhadap nilai perusahaan. Hasil ini mengindikasikan semakin tinggi Investment Opportunity Set maka nilai perusahaan semakin tinggi juga.

2. Dividen Payout Ratio tidak berpengaruh positif terhadap nilai perusahaan.

3. Hasil penelitian yang terkait dengan mekanisme corporate governance yaitu.:

- Komite audit tidak berpengaruh positif terhadap nilai perusahaan.

- Komposisi komisaris independen berpengaruh positif terhadap nilai perusahaan.

- Kepemilikan institusional berpengaruh positif terhadap nilai perusahaan.

- Kepemilikan manajerial berpengaruh positif terhadap nilai perusahaan.

\section{Keterbatasan Penelitian}

Beberapa keterbatasan yang ada dalam penelitian ini, antara lain:

1. Sampel yang digunakan dalam penelitian ini hanya perusahaan manufaktur, sehingga perlu penambahan sampel penelitian dari luar perusahaan manufaktur.

2. Nilai perusahaan dalam penelitian ini diukur menggunakan Tobin's Q, yang mana masih ada proksi lain untuk menghitung nilai perusahaan seperti PBV.

3. Penelitian ini hanya menggunakan satu karakteristik variabel dummy yaitu variabel komite audit.

\section{Saran}

1. Untuk penelitian selanjutnya sebaiknya menggunakan sampel dari sektor lain selain manufaktur.

2. Untuk penelitian selanjutnya bisa menggunakan ukuran lain untuk mengukur nilai perusahaan, seperti PBV atau proksi lainnya.

3. Untuk penelitian selanjutnya bisa menggunakan ukuran yang lain untuk komite audit, seperti persentase komposisi komite audit didalam perusahaan. 


\section{DAFTAR PUSTAKA}

Brigham, E.F, Gapenski, Louis C, Intermediate Finance Management, Edisi 5, The Dryden Press, Harbor Drive, 1996.

Chen $Y$, Corporate Goverannce and Cash Holdings: Listed New Economy Versus Old Economy Firms, Corporate Governance, Vol. 16 No.5, Hal. 430-442, 2008.

Darmawati, et al. (2005). Hubungan Corporate Governance dan Kinerja Perusahaan. Jurnal Riset Akuntansi Indonesia. Vol. 8, No. 6

Etty Murwaningsari, Konflik Kepentingan Manajerial Pada Pemilihan Metode Akuntansi Persediaan, Balances, Vol. 1, 2009, Hal. 1-12.

Fama, E.F, Agency Problems and The Theory of The Firm, Journal of Political Economy 88, Vol: 2, 1978, Hal. 289-307.

Herawaty, Vinolla. 2008. "Peran Praktek Corporate Governance sebagai Moderating Variable dari Pengaruh Earnings Management terhadap Nilai Perusahaan", Jurnal Akuntansi dan Keuangan, Vol. 10, No. 2, pp. 97-108.

Jensen, M.C, W. H. Meckling, Theory of The Firm: Manajerial Behaviour, Agency Cost, and Ownership Structure, Journal of Financial and Economics, Vol. 3, 1976, Hal. 305-360.

Kallapur, Sanjay, Mark A. Trombley, The Investment Opportunity Set: Determinants, Consequences and Measurement, Managerial Finance, Vol. 27, 2001, Hal. 3-15.

Modigliani, F. and Miller, M.H. (1958). The cost of capital, corporation finance and the theory of investment. American Economic Review. Vol. 48, No. 3. (Jun., 1958), pp. 261-297

Rachmawati, Hanung Triatmoko, Analisis Faktor-Faktor yang Mempengaruhi Kualitas Laba dan Nilai Perusahaan, Simposium Nasional Akuntansi X, Makasar, 26-28 Juli 2007.

Rika Susanti, Analisis Faktor-Faktor yang Berpengaruh Terhadap Nilai Perusahaan, Skripsi S-1, Fakultas Ekonomi, Universitas Diponegoro, Semarang, 2010.

Siallagan Hamonangan, Mas'ud Machfoedz, Mekanisme Corporate Governance, Kualitas Laba dan Nilai Perusahaan, Simposium Nasional Akuntansi IX. Padang, 23-26 Agustus 2006.

Sri Hasnawati, Dampak Set Peluang Investasi Terhadap Nilai Perusahaan Publik di Bursa Efek Jakarta, Jurnal Akuntansi dan Auditing Indonesia, Vol. 9, No. 2, 2005, Hal. 117-126.

Wahyudi Untung, Pawestri, P. Hartini, Implikasi Struktur Kepemilikan Terhadap Nilai Perusahaan Dengan Keputusan Keuangan Sebagai Variabel Intervening, Simposium Nasional Akutansi Xl, Padang, 23-26 Agustus 2006.

Xie, Biao, Wallace N. Davidson $/ l l$ dan Peter J. Dadalt. 2003. Earnings Management and Corporate Governance: The Role of The Board and the Audit Committee. Journal of Corporate Finance. Vol. 9. Juni: 295-316.

Zanigina Isshaq, Corporate Governance, Ownership Structure, Cash Holding, and Firm Value on The Ghana Stock Exchange, The Journal of Risk Finance, Vol.10, No.5, 2009, Hal. 488499.

Indonesian Capital Market Directory (ICMD), 2010, Jakarta: Bursa Efek Indonesia.

www.idx.co.id 